\title{
Global Change and the Soil Microbiome: A Human-Health Perspective
}

\author{
Raúl Ochoa-Hueso * \\ Department of Ecology, Autonomous University of Madrid, Madrid, Spain
}

\section{OPEN ACCESS}

Edited by:

Mark A. Elgar,

University of Melbourne, Australia

Reviewed by:

Nathaniel Newlands,

Agriculture and Agri-Food Canada,

Government of Canada, Canada

Carlos M. Duarte,

King Abdullah University of Science

and Technology, Saudi Arabia

*Correspondence:

Raúl Ochoa-Hueso

rochoahueso@gmail.com

Specialty section:

This article was submitted to Interdisciplinary Climate Studies,

a section of the journal

Frontiers in Ecology and Evolution

Received: 28 July 2016

Accepted: 19 June 2017

Published: 06 July 2017

Citation:

Ochoa-Hueso R (2017) Global Change and the Soil Microbiome: A

Human-Health Perspective.

Front. Ecol. Evol. 5:71.

doi: 10.3389/fevo.2017.00071
The importance of the gut and the soil microbiomes as determinants of human and ecosystem health, respectively, is gaining rapid acceptation in the medical and ecological literatures. This suggests that there is a wealth of highly transferable knowledge about the microbial ecology of human and non-human ecosystems that is currently being generated in parallel, but mostly in isolation from one another. I suggest that effectively sharing this knowledge could greatly help at more efficiently understanding and restoring human health and the functioning of ecosystems, which are currently under wide-spread pressure. I illustrate this by comparing the effects of nitrogen deposition on ecosystem carbon sequestration with unhealthy dietary habits and human disease. The deposition of $\mathrm{N}$, a key nutrient for plant growth, may increase carbon sequestration (equivalent to obesity) through several mechanisms, including a reduction in the ability of soil microbes to process organic matter, which some argue could help mitigate climate change. However, this usually results in a degradation of ecosystem health and, thus, cannot represent a real solution. Similarly, human obesity is linked to an alteration of the composition and functioning of microbial communities inhabiting the gut, which is often attributed to unhealthy dietary habits, including ingesting high amounts of simple sugars and processed foods. Finally, I advocate for the explicit recognition of the many commonalities between the functioning of the gut and ecosystems and a broader multidisciplinary collaboration among experts in ecology and human health, including the engineering of soil microbial communities designed ad-hoc to restore ecosystem health.

Keywords: carbon sequestration, climate change mitigation, ecosystem health, human health, microbiome, nitrogen deposition, probiotics, synbiotics

\section{NITROGEN DEPOSITION AND CARBON SEQUESTRATION IN A CHANGING CLIMATE}

It has been widely proposed that atmospheric nitrogen $(\mathrm{N})$ deposition could help mitigate climate change by increasing the rates of carbon (C) sequestration in terrestrial ecosystems (Knorr et al., 2005; Reich et al., 2006; Yue et al., 2016). Two commonly observed responses are typically proposed as mechanisms: first, a greater amount of $\mathrm{N}$ usually implies a higher capacity for plant growth, which would result in a greater amount of $\mathrm{C}$ retained within the system (Magnani et al., 2007; de Vries et al., 2009; Laubhann et al., 2009). Of course, for this to be true, it is necessary that the increase in the rates of $\mathrm{C}$ uptake and accumulation exceed the $\mathrm{C}$ emission rates, whatever the main route by which the latter happens, including plant and/or microbial respiration and changes in fire dynamics due to an excess 
of biomass accumulation (Dezi et al., 2010; Fenn et al., 2010). The second main mechanism is linked to a reduction in decomposition rates, particularly of recalcitrant organic matter, which would, therefore, accumulate within the system (Knorr et al., 2005; Waldrop and Zak, 2006). Otherwise, this accumulated $\mathrm{C}$ may be lost to the atmosphere in the form of $\mathrm{CO}_{2}$ after being respired by soil microorganisms (Janssens et al., 2010). Of course, the relative importance of these mechanisms depend on how plant communities and soil microorganisms respond, directly and indirectly, to the additional inputs of $\mathrm{N}$ which, in any case, usually ends up resulting in a disruption of the interaction between these two key components of the ecosystem (Liu et al., 2014).

\section{THE NEED FOR A NEW PERSPECTIVE}

In this article, I will adopt a human health perspective, hardly used in the discipline of global change ecology, to substantiate why atmospheric $\mathrm{N}$ deposition cannot represent a positive (i.e., healthy) alternative to mitigate climate change. In the medical literature, it is now widely recognized that human beings are like ecosystems (in fact, some consider us as living ecosystems) in which the eukaryotic cells that form part of our bodies and the prokaryotic cells that live in and on us are deeply interconnected, whereas the enormous importance of our microbiome to human health is also increasingly gaining acceptation (Bengmark, 1998; Berendsen et al., 2012; Ha et al., 2014; Alivisatos et al., 2015; Tilg and Adolph, 2015; Blaser, 2016; Blaser et al., 2016). The fact that many modern diseases, including conditions of the nervous and circulatory systems, skin and heart and allergies (including atopic dermatitis and food allergies), are directly caused by alterations in the microbial communities that live in our interior and exterior is also gaining rapid acceptation (Ha et al., 2014; Tilg and Adolph, 2015; Chang et al., 2016; Tang and Lodge, 2016). In this sense, the word ecosystem is widely used in the current literature of integrative medicine and gastroenterology. However, the opposite does not frequently happen in ecology [i.e., (cautiously) comparing ecosystems with the human body], despite the wealth of knowledge in the medical and human health literature that we, as ecologists, could apply in, for example, issues related to understanding the functioning (i.e., metabolism) of ecosystems and plant-soil-microbe interactions subjected to human pressure (Berendsen et al., 2012; Blaser et al., 2016; Table 1; Figure 1). Therefore, I will finally defend the need to approach problems in ecology from a more multidisciplinary, fresher perspective.

\section{WHY NITROGEN DEPOSITION CANNOT BE THE SOLUTION TO CLIMATE CHANGE}

The reason why I think that a temporary, $\mathrm{N}$ deposition-induced increase in the rate of $\mathrm{C}$ sequestration will not contribute to mitigating climate change in the long term is equivalent to the reason of those that argue that an increase in obesity rates in human populations derived from a diet rich in simple sugars and processed food and the consequent alteration of their microbiome will not successfully and permanently solve any public health problem of today's societies. Ingesting large amounts of simple sugars, processed foods, sugary drinks and saturated fats is definitely better than starving, but that does not mean that it is a healthy practice. And the same happens with $\mathrm{N}$ deposition and $\mathrm{C}$ sequestration. In ecosystems where $\mathrm{N}$ is still a limiting nutrient, which is quite common worldwide (LeBauer and Treseder, 2008), an increase in the availability of $\mathrm{N}$ can increase ecosystem productivity to levels comparable to human obesity (Tian et al., 2016), but that does not mean that the ecosystem is healthier and, therefore, that this will result in a long-term benefit (Bobbink et al., 2010; Jones et al., 2014). In this sense, a healthy ecosystem may be defined here as a highly multifunctional ecosystem that can maintain an adequate supply of services, at least as compared to a previously defined reference state.

In medicine, the term dysbiosis refers to changes in the composition of the microbiome that are not beneficial to the individuals, including a loss of abundance and diversity of beneficial microorganisms and increased number of pathogens, and that result in the development of a condition ( $\mathrm{Ha}$ et al., 2014; Tilg and Adolph, 2015). This term could also be used to describe ecosystems that are dysfunctional due to alterations of their microbial communities. In this sense, it has been repeatedly shown through experimental studies and meta-analyses that increased $\mathrm{N}$ deposition is typically associated with changes in soil microbial communities (usually related to a decrease in abundance and biodiversity; Treseder, 2004, 2008; Ramirez et al., 2010; Zeng et al., 2015), reduced ecosystem functionality (alterations of energy metabolism; Waldrop and Zak, 2006; Treseder, 2008; Liu et al., 2014) and short- to mid-term increases in $\mathrm{C}$ sequestration, especially in aboveground biomass, but also in the soil and roots (comparable to obesity, as previously mentioned; Xia and Wan, 2008; Yue et al., 2016). Given that metabolic disorders and obesity in humans are clearly associated with a deterioration in the health status of individuals that may even result in cases of fatality due to chronic diseases, sudden death or, quite commonly in the natural world, to increased sensitivity to other environmental stresses (Mathur and Barlow, 2015; Monteiro et al., 2015), I think that we would do well to be cautious when we consider, perhaps naively, the potential benefits of a $\mathrm{N}$ that, after all, is the result of the atmospheric pollution derived from our activities (Gruber and Galloway, 2008).

\section{THE "DECEPTIVELY SIMPLE” SOLUTION}

The connections between human health, disease, and the microbiome, especially in the case of the gut, are becoming increasingly apparent and are attracting the public attention, especially because of the high social cost of unhealthy dietary habits and lifestyles and the "deceptively simple" solution of the problem (Mathur and Barlow, 2015; Tilg and Adolph, 2015; Blaser, 2016). In the case of both people and ecosystems, (i) ensuring a healthy supply of nutrients derived from the breakdown and cycling of unprocessed food/organic matter, (ii) minimizing the use of antibiotics (particularly those associated 


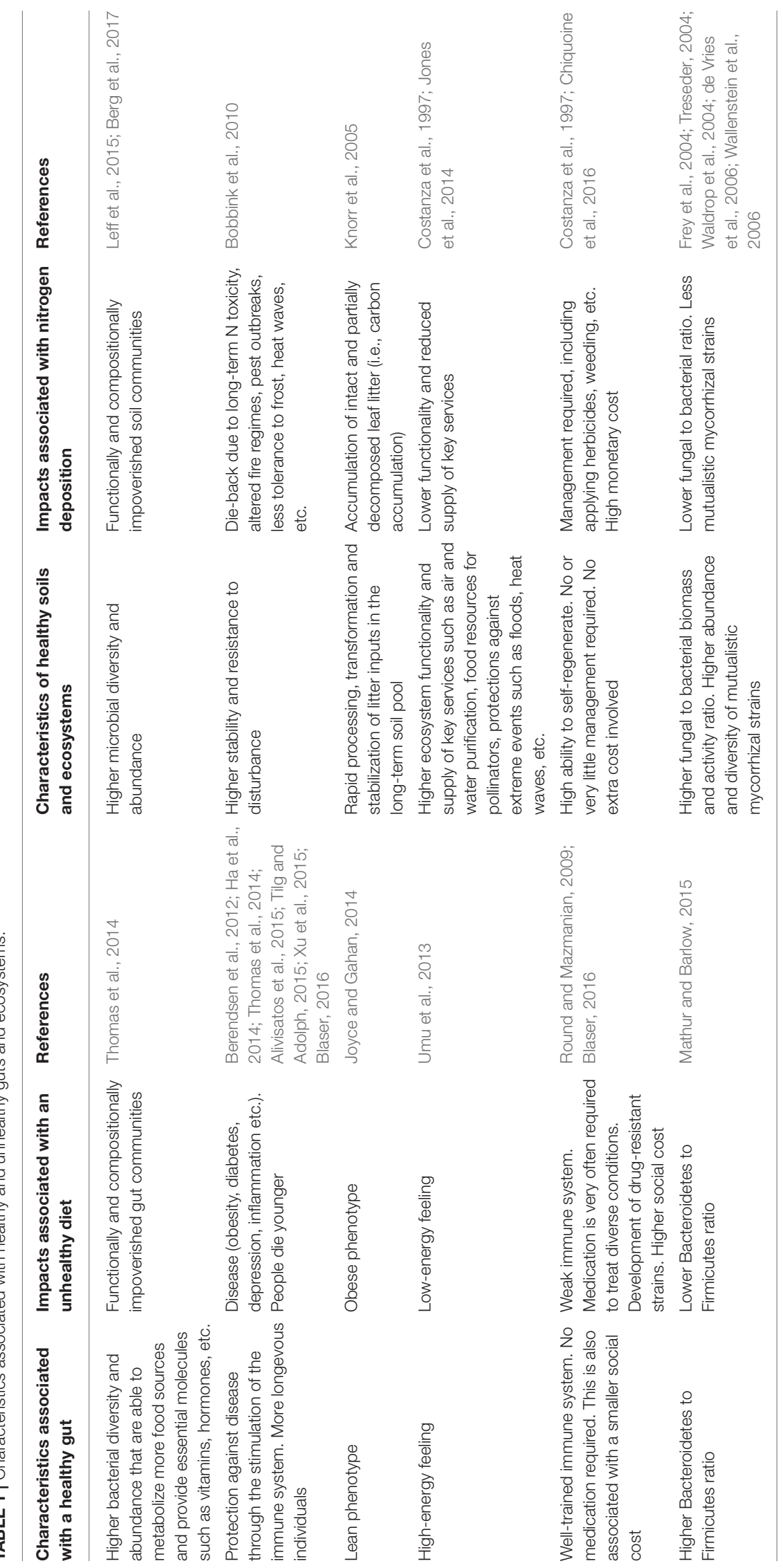




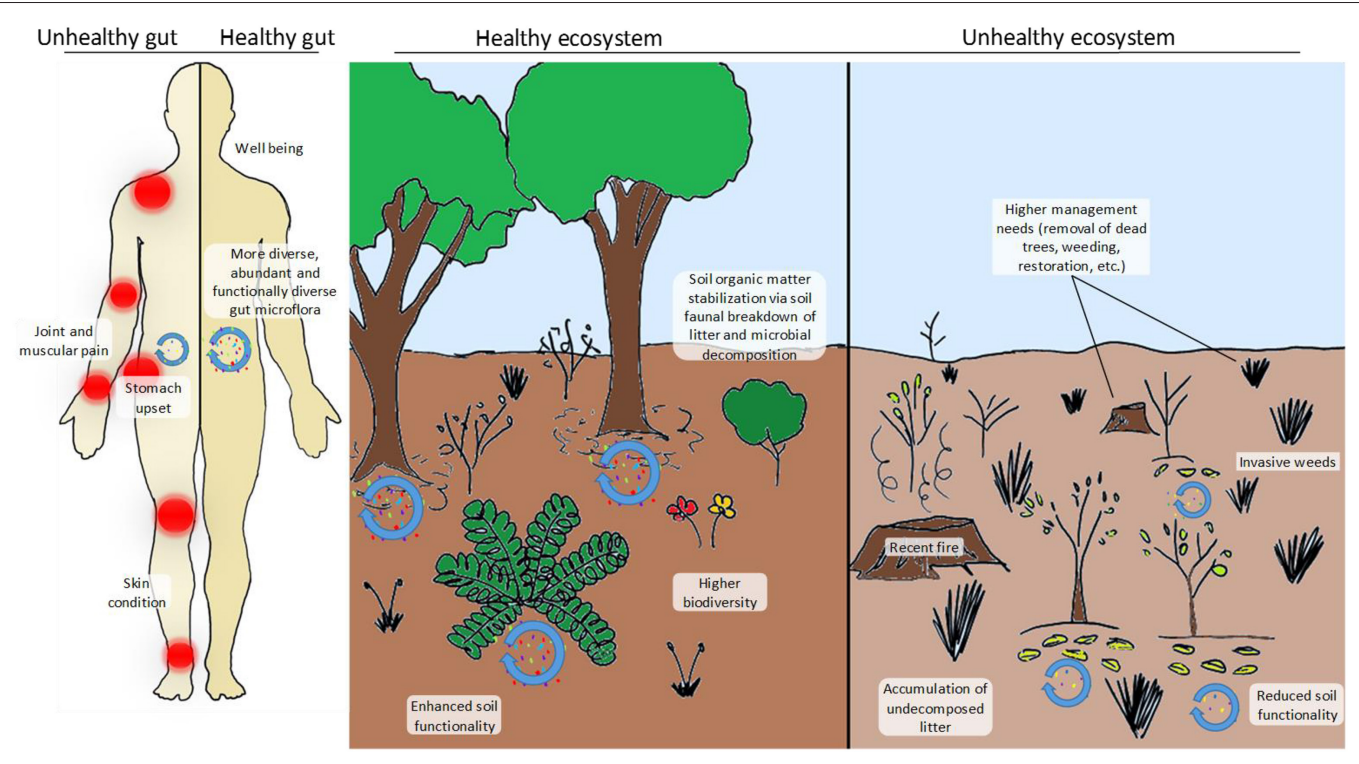

FIGURE 1 | Comparison between a healthy and an unhealthy gut (left-hand side panel) and a healthy and an unhealthy ecosystem (right-hand side panel). In the case of the human individual, his/her gut microbiota is less diverse ("red" microbes are completely absent), less abundant and contains more pathogenic taxa ("yellow" microbes). The individual with the healthy gut has a more functional and more abundant microbiota that provides him/her with essential nutrients, hormones, amino acids, etc. and stimulates his/her immune system. A healthy gut is also less prone to become infected by pathogens and can process toxic compounds (i.e., detoxify) more easily. The disturbed (i.e., unhealthy) ecosystem shown here has recently been affected by a devastating fire fuelled by the accumulation of $\mathrm{N}$-loving exotic grasses that have altered the natural fire dynamics of the system. Facilitated by the altered fire dynamics, the system has also become chronically dominated by weedy grasses, therefore requiring intensive (and costly) management practices (dead tree removal, weeding and restoration), also posing a threat to nearby human populations and their properties. Biodiversity (in terms of microbial, faunal and plant communities) is remarkably higher in the healthy ecosystem, which also has a higher potential to process organic matter inputs and stabilize them in the long-term soil pool. In contrast, undecomposed or partially decomposed litter accumulates on the functionally impoverished soil of the unhealthy ecosystem. This pattern is in agreement with reported observations of higher soil carbon sequestration under increased nitrogen deposition scenarios due to the inhibition of soil enzymes and the reduction of microbial biomass but poses relevant questions such as: Is this type of $\mathrm{N}$ deposition-induced carbon sequestration desirable? And, does it really represent a long-term (or even short-term) solution?

with the livestock industry in the case of ecosystems; Park and Choi, 2008) and chemicals (including herbicides and pesticides in the case of ecosystems) that destroy the microbiome, unless this is strictly necessary, and (iii) promoting practices that favor the system's ability to self-regenerate, something that living systems do wonderfully well, and that increase its resilience against pathogens and extreme events could be part of the solution, if not all, of the problem.

Of course, there are opportunities to aid in the recovery of our damaged and degraded ecosystems as well as there are possibilities to recover the lost or damaged intestinal flora (Brudnak, 2002; Sheth et al., 2016). This can be achieved by the use of properly designed probiotics or fecal transplants or, in the case of ecosystems, inocula assembled in the lab from pure cultures or soil samples obtained in the field from healthy ecosystems (Bowker, 2007; Chiquoine et al., 2016; Wubs et al., 2016) in conjunction with a balanced nutrient supply (i.e., organic matter inputs, the equivalent to prebiotics; Mathur and Barlow, 2015; Sheth et al., 2016). In this sense, the concept of synbiotics (i.e., synchronous administration of probiotics and prebiotics) could represent a particularly promising benchmark borrowed from the human health literature to successfully restore degraded ecosystems (Tang and Lodge, 2016) and, thus, the human probiotics industry has an opportunity to play a key role in this development.

\section{CONCLUDING REMARKS}

Recognizing and understanding the similarities and deep connections between the gut and the belowground world, where roots are the equivalent to our gut and the rhizosphere is the gut microflora (Berendsen et al., 2012) can help us advance the understanding of ecosystems by leaps and bounds through the search of similar microbial indicators of disease (e.g., Bacteroidetes to Firmicutes ratio in humans; Mathur and Barlow, 2015) and, therefore, to implement quick and successful measures in ecosystem management rather than relying, perhaps naively, on that the very same thing that caused climate change (i.e., pollutant emissions to the atmosphere) will also be part of the solution. From here, I advocate for the development of a new field of research that specifically aims at recognizing and make practical use of the profound links between the functioning of the gut and the ecosystems that extend beyond our bodies and that benefits from a truly multidisciplinary collaboration among experts in the areas of global change ecology and human health. 


\section{AUTHOR CONTRIBUTIONS}

The author confirms being the sole contributor of this work and approved it for publication.

\section{REFERENCES}

Alivisatos, A. P., Blaser, M. J., Brodie, E. L., Chun, M., Dangl, J. L., Donohue, T. J. et al. (2015). A unified initiative to harness Earth's microbiomes. Science 350, 507-508. doi: 10.1126/science.aac 8480

Bengmark, S. (1998). Ecological control of the gastrointestinal tract. The role of probiotic flora. Gut 42, 2-7. doi: 10.1136/gut.42.1.2

Berendsen, R. L., Pieterse, C. M. J., and Bakker, P. A. H. M. (2012). The rhizosphere microbiome and plant health. Trends Plant Sci. 17, 478-486. doi: 10.1016/j.tplants.2012.04.001

Berg, G., Köberl, M., Rybakova, D., Müller, H., Grosch, R., Smalla, K. (2017). Plant microbial diversity is suggested as the key to future biocontrol and health trends. FEMS Microbiol. Ecol. 93, fix050-fix050.

Blaser, M. J. (2016). Antibiotic use and its consequences for the normal microbiome. Science 6285, 544-545. doi: 10.1126/science.aad9358

Blaser, M. J., Cardon, Z. G., Cho, M. K., Dangl, J. L., Donohue, T. J., Green, J. L., et al. (2016). Toward a predictive understanding of Earth's microbiomes to address 21st century challenges. MBio. 7, e00714-16. doi: 10.1128/mBio.00714-16

Bobbink, R., Hicks, K., Galloway, J., Spranger, T., Alkemade, R., Ashmore, M., et al. (2010). Global assessment of nitrogen deposition effects on terrestrial plant diversity: a synthesis. Ecol. Appl. 20, 30-59. doi: 10.1890/08-1140.1

Bowker, M. A. (2007). Biological soil crust rehabilitation in theory and practice: an underexploited opportunity. Restor. Ecol. 15, 13-23. doi: 10.1111/j.1526-100X. 2006.00185.x

Brudnak, M. A. (2002). Weight-loss drugs and supplements: are there safer alternatives? Med. Hypotheses 58, 28-33. doi: 10.1054/mehy.2001.1444

Chang, Y. S., Trivedi, M. K., Jha, A., Lin, Y.-F., Dimaano, L., García-Romero, M. T., et al. (2016). Synbiotics for prevention and treatment of atopic dermatitis: a meta-analysis of randomized clinical trials. JAMA Pediatr. 170, 236-242. doi: 10.1001/jamapediatrics.2015.3943

Chiquoine, L. P., Abella, S. R., and Bowker, M. A. (2016). Rapidly restoring biological soil crusts and ecosystem functions in a severely disturbed desert ecosystem. Ecol. Appl. 26, 1260-1272. doi: 10.1002/15-0973

Costanza, R., Arge, R., De Groot, R., Farberk, S., Grasso, M., Hannon, B., et al. (1997). The value of the world's ecosystem services and natural capital. Nature 387, 253-260. doi: 10.1038/387253a0

de Vries, F. T., Hoffland, E., van Eekeren, N., Brussaard, L., and Bloem, J. (2006). Fungal/bacterial ratios in grasslands with contrasting nitrogen management. Soil Biol. Biochem. 38, 2092-2103. doi: 10.1016/j.soilbio.2006.01.008

de Vries, W., Solberg, S., Dobbertin, M., Sterba, H., Laubhann, D., van Oijen, M., et al. (2009). The impact of nitrogen deposition on carbon sequestration by European forests and heathlands. For. Ecol. Manage. 258, 1814-1823. doi: 10.1016/j.foreco.2009.02.034

Dezi, S., Medlyn, B. E., Tonon, G., and Magnani, F. (2010). The effect of nitrogen deposition on forest carbon sequestration: a model-based analysis. Glob. Chang. Biol. 16, 1470-1486. doi: 10.1111/j.1365-2486.2009.02102.x

Fenn, M. E., Allen, E. B., Weiss, S. B., Jovan, S., Geiser, L. H., Tonnesen, G. S., et al. (2010). Nitrogen critical loads and management alternatives for $\mathrm{N}$-impacted ecosystems in California. J. Environ. Manage. 91, 2404-2423. doi: 10.1016/j.jenvman.2010.07.034

Frey, S. D., Knorr, M., Parrent, J. M., and Simpson, R. T. (2004). Chronic nitrogen enrichment affects the structure and function of the soil microbial community in temperate hardwood and pine forests. For. Ecol. Manage. 196, 159-171. doi: 10.1016/j.foreco.2004.03.018

Gruber, N., and Galloway, J. N. (2008). An Earth-system perspective of the global nitrogen cycle. Nature 451, 293-296. doi: 10.1038/nature06592

Ha, C. Y., Lam, Y., and Holmes, A. J. (2014). Mechanistic links between gut microbial community dynamics, microbial functions and metabolic health. World J. Gastroenterol. 20, 16498-16517. doi: 10.3748/wjg.v20.i44.16498

\section{ACKNOWLEDGMENTS}

I am indebted to Dr. Lilia Serrano for her tirelessly encouragement to write this opinion article.

Janssens, I. A., Dieleman, W., Luyssaert, S., Subke, J.-A., Reichstein, M., Ceulemans, R., et al. (2010). Reduction of forest soil respiration in response to nitrogen deposition. Nat. Geosci. 3, 315-322. doi: 10.1038/ngeo844

Jones, L., Provins, A., Holland, M., Mills, G., Hayes, F., Emmett, B., et al. (2014). A review and application of the evidence for nitrogen impacts on ecosystem services. Ecosyst. Serv. 7, 76-88. doi: 10.1016/j.ecoser.2013.09.001

Joyce, S. A., and Gahan, C. G. M. (2014). The gut microbiota and the metabolic health of the host. Curr. Opin. Gastroenterol. 30, 120-127. doi: 10.1097/MOG.0000000000000039

Knorr, M., Frey, S. D. S., and Curtis, P. S. (2005). Nitrogen additions and litter decomposition: a meta-analysis. Ecology 86, 3252-3257. doi: 10.1890/05-0150

Laubhann, D., Sterba, H., Reinds, G. J., and De Vries, W. (2009). The impact of atmospheric deposition and climate on forest growth in European monitoring plots: an individual tree growth model. For. Ecol. Manage. 258, 1751-1761. doi: 10.1016/j.foreco.2008.09.050

LeBauer, D. S., and Treseder, K. K. (2008). Nitrogen limitation of net primary productivity in terrestrial ecosystems is globally distributed. Ecology 89, 371-379. doi: 10.1890/06-2057.1

Leff, J. W., Jones, S. E., Prober, S. M., Barberán, A., Borer, E. T., Firn, J. L., et al. (2015). Consistent responses of soil microbial communities to elevated nutrient inputs in grasslands across the globe. Proc. Natl. Acad. Sci. U.S.A. 112, 10967-10972. doi: 10.1073/pnas.1508382112

Liu, W., Jiang, L., Hu, S., Li, L., Liu, L., Wan, S. et al. (2014). Decoupling of soil microbes and plants with increasing anthropogenic nitrogen inputs in a temperate steppe. Soil Biol. Biochem. 72, 116-122. doi: 10.1016/j.soilbio.2014.01.022

Magnani, F., Mencuccini, M., Borghetti, M., Berbigier, P., Berninger, F., Delzon, S., et al. (2007). The human footprint in the carbon cycle of temperate and boreal forests. Nature 447, 848-850. doi: 10.1038/nature05847

Mathur, R., and Barlow, G. M. (2015). Obesity and the microbiome. Expert Rev. Gastroenterol. Hepatol. 9, 1087-1099. doi: 10.1586/17474124.2015.1051029

Monteiro, J. P., Kussmann, M., and Kaput, J. (2015). The genomics of micronutrient requirements. Genes Nutr. 10:466. doi: 10.1007/s12263015-0466-2

Park, S., and Choi, K. (2008). Hazard assessment of commonly used agricultural antibiotics on aquatic ecosystems. Ecotoxicology 17, 526-538. doi: 10.1007/s10646-008-0209-x

Ramirez, K. S., Lauber, C. L., Knight, R., Bradford, M. A., and Fierer, N. (2010). Consistent effects of nitrogen fertilization on soil bacterial communities in contrasting systems. Ecology 91, 3414-3463. doi: 10.1890/10-0426.1

Reich, P. B., Hungate, B. A., and Luo, Y. (2006). Carbon-nitrogen interactions in terrestrial ecosystems in response to rising atmospheric carbon dioxide. Annu. Rev. Ecol. Evol. Syst. 37, 611-636. doi: 10.1146/annurev.ecolsys.37.091305.110039

Round, J. L., and Mazmanian, S. K. (2009). The gut microbiota shapes intestinal immune responses during health and disease. Nat. Rev. Immunol. 9, 313-323. doi: 10.1038/nri2515

Sheth, R. U., Cabral, V., Chen, S. P., and Wang, H. H. (2016). Manipulating bacterial communities by in situ microbiome engineering. Trends Genet. 32, 189-200. doi: 10.1016/j.tig.2016.01.005

Tang, M. L., and Lodge, C. J. J. (2016). Examining the evidence for using synbiotics to treat or prevent atopic dermatitis. JAMA Pediatr. 170, 201-203. doi: 10.1001/jamapediatrics.2015.4406

Thomas, L. V., Ockhuizen, T., and Suzuki, K. (2014). Exploring the influence of the gut microbiota and probiotics on health: a symposium report. Br. J. Nutr. 112(Suppl. 1), S1-S18. doi: 10.1017/S00071145140 01275

Tian, D., Wang, H., Sun, J., and Niu, S. (2016). Global evidence on nitrogen saturation of terrestrial ecosystem net primary productivity. Environ. Res. Lett. 11:24012. doi: 10.1088/1748-9326/11/2/024012 
Tilg, H., and Adolph, T. E. (2015). Influence of the human intestinal microbiome on obesity and metabolic dysfunction. Curr. Opin. Pediatr. 26, 496-501. doi: 10.1097/MOP.0000000000000234

Treseder, K. K. (2004). A meta-analysis of mycorrhizal responses to nitrogen, phosphorus, and atmospheric $\mathrm{CO}_{2}$ in field studies. New Phytol. 164, 347-355. doi: 10.1111/j.1469-8137.2004.01159.x

Treseder, K. K. (2008). Nitrogen additions and microbial biomass: a metaanalysis of ecosystem studies. Ecol. Lett. 11, 1111-1120. doi: 10.1111/j.14610248.2008.01230.x

Umu, O. C., Oostindjer, M., Pope, P. B., Svihus, B., Egelandsdal, B., and Nes, I. F. (2013). Potential applications of gut microbiota to control human physiology. Antonie Van Leeuwenhoek 104, 609-618. doi: 10.1007/s10482-013-0008-0

Waldrop, M. P., and Zak, D. R. (2006). Response of oxidative enzyme activities to nitrogen deposition affects soil concentrations of dissolved organic carbon. Ecosystems 9, 921-933. doi: 10.1007/s10021-004-0149-0

Waldrop, M. P., Zak, D. R., and Sinsabaugh, R. L. (2004). Microbial community response to nitrogen deposition in northern forest ecosystems. Soil Biol. Biochem. 36, 1443-1451. doi: 10.1016/j.soilbio.2004.04.023

Wallenstein, M. D., McNulty, S., Fernandez, I. J., Boggs, J., and Schlesinger, W. H. (2006). Nitrogen fertilization decreases forest soil fungal and bacterial biomass in three long-term experiments. For. Ecol. Manage. 222, 459-468. doi: 10.1016/ j.foreco.2005.11.002

Wubs, E. R. J., Putten, W. H., van der Bosch, M., and Bezemer, T. M. (2016). Soil inoculation steers restoration of terrestrial ecosystems. Nat Plants 2:16107. doi: $10.1038 /$ nplants.2016.107
Xia, J., and Wan, S. (2008). Global response patterns of terrestrial plant species to nitrogen addition. New Phytol. 179, 428-439. doi: 10.1111/j.14698137.2008.02488.x

Xu, X., Wang, Z., and Zhang, X. (2015). The human microbiota associated with overall health. Crit. Rev. Biotechnol. 35, 129-140. doi: 10.3109/07388551. 2013.819485

Yue, K., Peng, Y., Peng, C., Yang, W., Peng, X., Wu, F., et al. (2016). Stimulation of terrestrial ecosystem carbon storage by nitrogen addition: a meta-analysis. Sci. Rep. 6:19895. doi: 10.1038/srep 19895

Zeng, J., Liu, X., Song, L., Lin, X., Zhang, H., Shen, C., et al. (2015). Nitrogen fertilization directly affects soil bacterial diversity and indirectly affects bacterial community composition. Soil Biol. Biochem. 92, 41-49.

Conflict of Interest Statement: The author declares that the research was conducted in the absence of any commercial or financial relationships that could be construed as a potential conflict of interest.

Copyright (C) 2017 Ochoa-Hueso. This is an open-access article distributed under the terms of the Creative Commons Attribution License (CC BY). The use, distribution or reproduction in other forums is permitted, provided the original author(s) or licensor are credited and that the original publication in this journal is cited, in accordance with accepted academic practice. No use, distribution or reproduction is permitted which does not comply with these terms. 